\title{
THE IMPORTANCE OF WNT PATHWAYS FOR BONE METABOLISM AND THEIR REGULATION BY IMPLANT TOPOGRAPHY
}

\author{
C. Galli ${ }^{1,2, *}$, M. Piemontese ${ }^{3}$, S. Lumetti ${ }^{1}$, E. Manfredi ${ }^{1}$, G.M. Macaluso ${ }^{1}$ and G. Passeri ${ }^{2}$ \\ ${ }^{1}$ Sez. Odontostomatologia, ${ }^{2}$ Dept. Internal Medicine and Biomedical School, \\ ${ }^{3}$ Dept. Experimental Medicine, University of Parma, Parma, Italy
}

\begin{abstract}
Endosseous implants are important tools to replace missing teeth or damaged tissue segments. Their clinical success depends on their integration in bone and, thus, on the response of bone cells to material and surface characteristics. Recent evidence has shown that surface topography and chemistry affect WNT signalling, a pivotal pathway for the commitment of mesenchymal progenitors to the osteoblast lineage and for bone homeostasis. WNT signalling comprises several cascades that, acting through different effectors, modulate several aspects of cell behaviour.

It has been shown that cells growing on rough titanium surfaces display a different expression profile for WNT factors, and that surface features can alter the response of bone cells to WNT factors. Although the underlying mechanisms to this regulation are still poorly understood, the present review reports intriguing evidence that that cell cytoskeletal signalling is involved in activating WNT signalling in cells growing on rough implant surfaces.
\end{abstract}

Keywords: Topography; WNT; titanium implants; osteoblasts; cytoskeleton.

*Address for correspondence:

Carlo Galli

Sez. Odontostomatologia

University of Parma

Via Gramsci 14, 43100 Parma, Italy

Telephone Number:+390521986722

FAX Number: +390521 292955

E-mail: carlo.galli@unipr.it

\section{Introduction}

Titanium endosseous implants are a versatile tool in medicine, with broad applications both in dentistry, where they are commonly used to support dental prosthesis, and orthopaedics, to replace damaged bone segments. The proper clinical function of an implant requires the formation of sound bone in close contact with the implant body, a process that is generally referred to as osseointegration (Brånemark, 1983; van Steenberghe $e t$ al., 1991). Mesenchymal cells and osteoblasts in particular, are the main players in this process, because they deposit the newly formed bone that will encase the implant. Their initial attachment, adhesion, and their response to implants are therefore critical determinants to the subsequent tissue reaction (Anselme et al., 2010; Anselme, 2011). All these events can be affected by the physical and chemical features of the substrate, such as its chemical composition, wettability, and topography, which can, in turn, affect the pattern of protein adsorption on the biomaterial surface. Several authors have shown that surface characteristics can alter cell growth and differentiation, the expression of extracellular matrix components and their mineralisation both in vitro (Keller et al., 2003; Schneider et al., 2003; Lossdorfer et al., 2004; Masaki et al., 2005; Arcelli et al., 2007; Wall et al., 2009; Liu et al., 2010; Wennerberg and Albrektsson, 2010; Donos et al., 2011a; Liu et al., 2012) and in vivo (Buser et al., 2004; Germanier et al., 2006; Gahlert et al., 2007; Bornstein et al., 2008; Coelho et al., 2011; Donos et al., 2011b; Ivanovski et al., 2011; Park, 2011; Kämmerer et al., 2012). The optimal implant characteristics to ameliorate their integration in bone, including roughness and texture, are however still the object of intense debate. To this purpose, a deeper understanding of the molecular pathways involved in osteoblast differentiation may prove decisive. Recently, the role of WNT signalling in bone formation has been elucidated, and it appears as a fundamental signalling cascade for osteoblast differentiation and bone formation. Recent evidence suggests that these complex pathways may also play a role in surface-induced osteoblast differentiation, and they could represent useful therapeutic targets to improve the clinical performance of endosseous implants. The aim of this review is therefore to examine the available evidence about the role of WNT signalling in bone formation and its regulation by implant surfaces.

\section{WNT signalling}

WNT signalling is activated by specific secreted $350-400$ amino acid long lipid-modified proteins (Cadigan and 

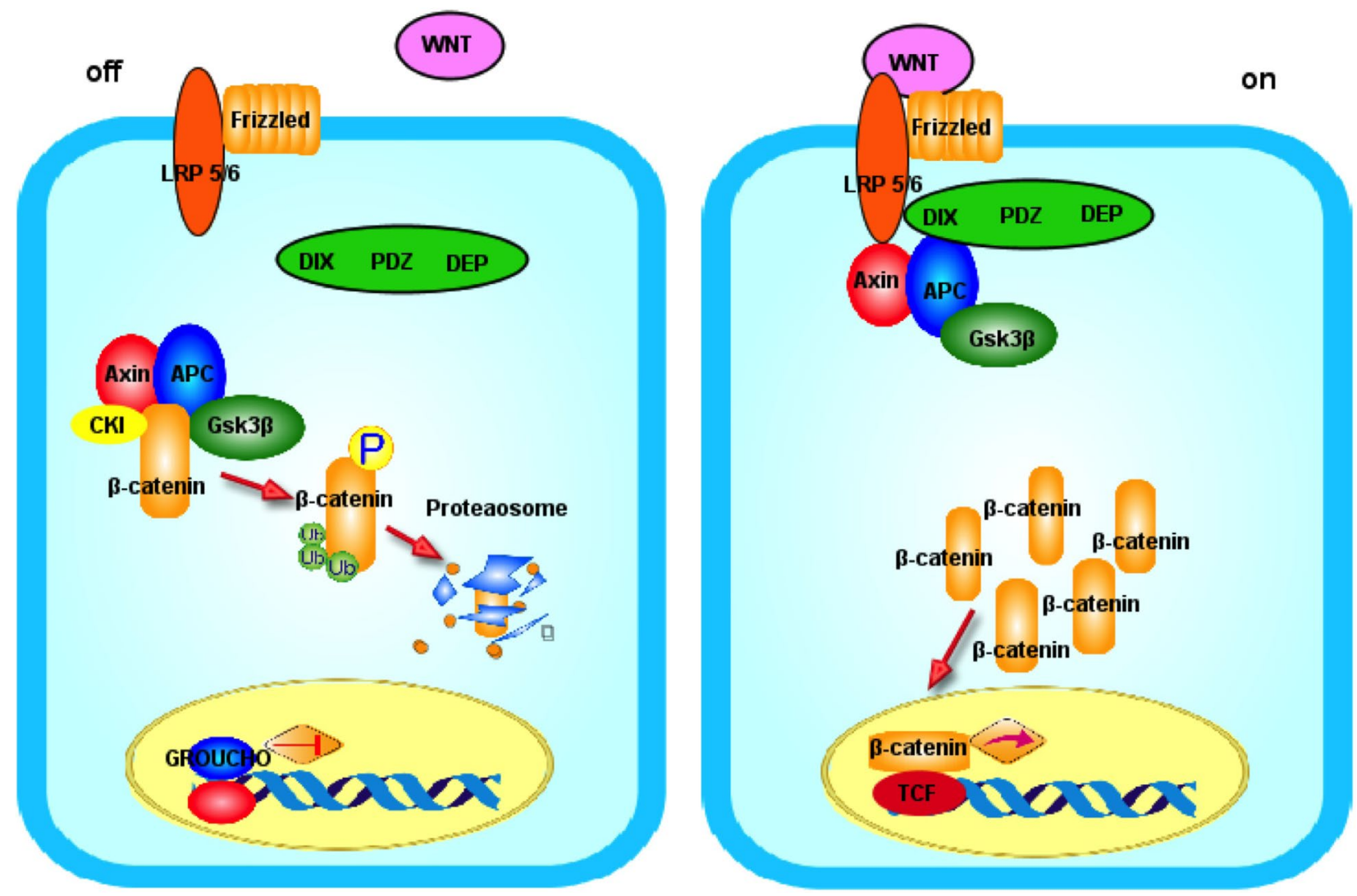

Fig. 1. Diagram showing the main molecular events during WNT canonical signalling. Cytoskeletal $\beta$-catenin is phosphorylated by a multimolecular complex and undergoes Ubiquitin ( $\mathrm{Ub}$ ) mediated degradation. Upon binding of specific WNT factors to a Frizzled-LRP receptor complex, the destruction complex is inhibited, thus allowing $\beta$-catenin to translocate to the nucleus and bind TCF/Lef.

Nusse, 1997; Katoh and Katoh, 2005). They are known to bind to a receptor complex comprising the Frizzled (Fzd) receptor (van Amerongen et al., 2008; Angers and Moon, 2009) and co-receptors that determine the activation of specific effectors (Mikels and Nusse, 2006). This results in the activation of several different molecular pathways: the WNT canonical pathway, which requires $\beta$-catenin (Fig. 1), and a number of so-called non-canonical WNT pathways, among which the Planar Cell Polarity (PCP) pathway and the $\mathrm{Ca}^{2+}$-dependent pathway are the best known (Fig. 2A,B).

\section{WNT canonical pathway}

The canonical or $\mathrm{WNT} / \beta$-catenin pathway requires binding of members of the WNT1 class (WNT1, WNT3, WNT3a, WNT7a, WNT7b, WNT8a) to Fzd and a member of the low-density lipoprotein receptor related protein family, LRP5/6 (Mikels and Nusse, 2006; van Amerongen and Nusse, 2009). This recruits Disheveled (Dvl) to the cell membrane and activates it (Lee et al., 2008; Turm et al., 2010). Dvl consists of three molecular domains: the N-terminal DIX domain, a central PDZ domain, and a C-terminal DEP domain (Axelrod et al., 1998; Boutros and Mlodzik, 1999; Wharton, 2003; Pan et al., 2004). Dvl is considered to play a pivotal role in regulating WNT-activated signalling cascades. It has been shown that the DIX and PDZ domains trigger $\beta$-catenin stabilisation (Kishida et al., 1999), while the PDZ and DEP domains are required for activation of WNT noncanonical cascades. In the absence of WNT stimulation, $\beta$-catenin is retained in the cytoplasm by a multi-protein degradation complex comprising Glycogen synthase kinase 3 (GSK3) (Force and Woodgett, 2009) and Casein kinase 1a (CKI) (Bernatik et al., 2011), and two scaffold proteins, Adenomatous polyposis coli (APC) (Tanneberger et al., 2011) and Axin (Chia and Costantini, 2005). This leads to $\beta$-catenin phosphorylation and its subsequent targeting for proteosomal degradation (Clevers, 2006; Verheyen and Gottardi, 2010).

$\beta$-catenin is a multirole protein that can act both as a normal constituent of cell-to-cell junctions by associating to membrane cadherins and as a co-transcription factor. It contains a central domain of 12 Armadillo repeats, which mediate most of the interactions of $\beta$-catenin with other proteins (Xu and Kimelman, 2007; Angers and Moon, 2009). Upon receptor activation, Frz binds to Dvl and the PPPS/TP motifs of LRP are phosphorylated, thus recruiting Axin and inhibiting GSK3 activity and the formation of the destruction complex. Recent evidence has demonstrated that LRPs can also be phosphorylated through an alternative, MAPK-dependent mechanism (Cervenka et al., 2011). These events cause the release of $\beta$-catenin, which then can translocate to the nucleus, where it interacts with a member of the $\mathrm{T}$ cell factor/lymphoid 

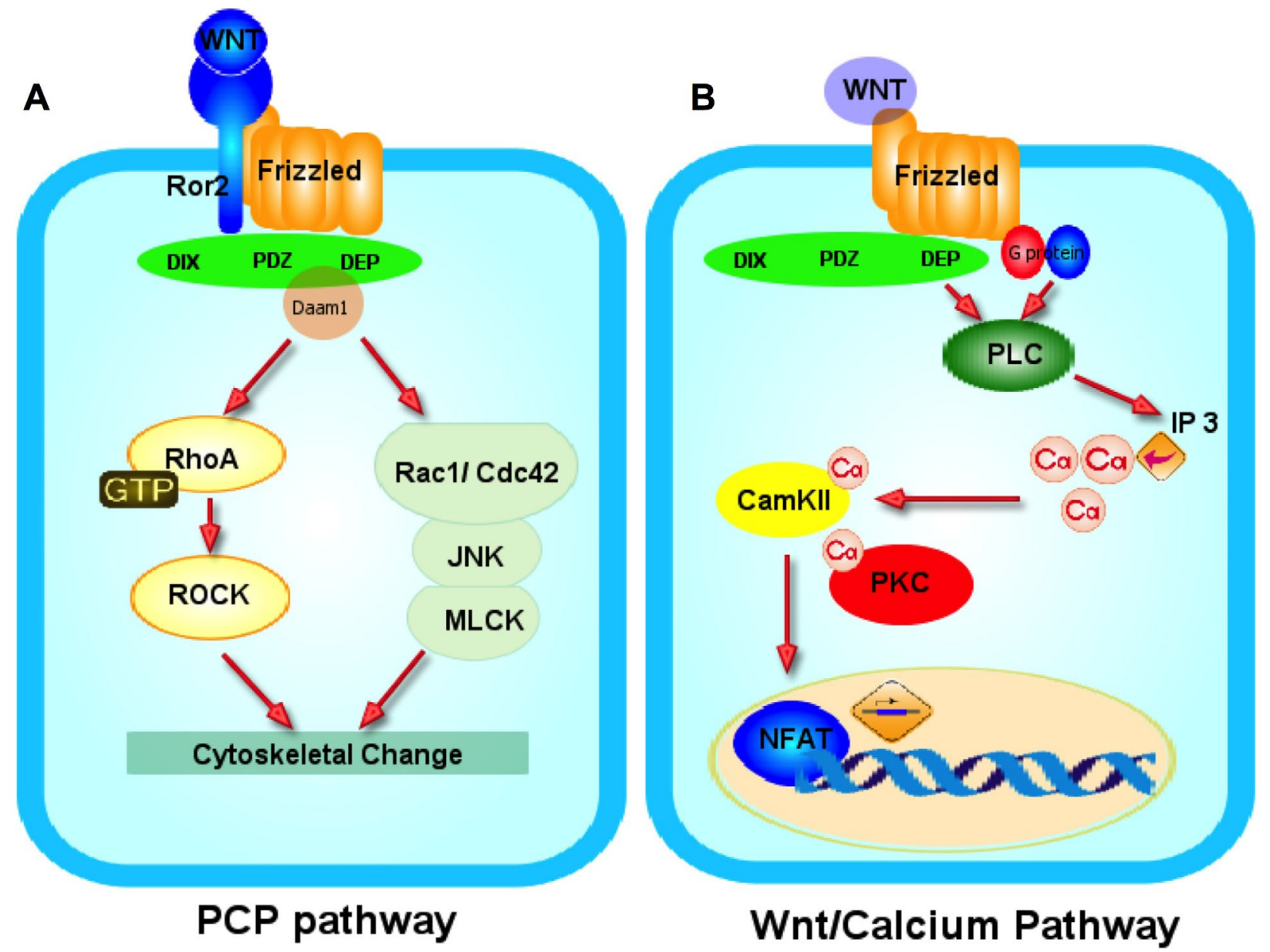

Fig. 2. Diagram summarising the non canonical Planar Cell Polarity (left panel) and Calcium-dependent (right panel) WNT signalling pathways. Both pathways activate Dishevelled (Dvl) but do not require $\beta$-catenin involvement, relying on direct activation of effectors controlling cytoskeletal rearrangement (PCP pathway) or $\mathrm{Ca}^{2+}-\mathrm{Calmodulin}$ activation.

enhancer factor (TCF/Lef1) transcription factor family (Mosimann et al., 2009), of which several members have been identified (Arce et al., 2006; Hoeppner et al., 2009). The binding of the first 50 amino acids of TCFs and the 3-10 Armadillo repeats of $\beta$-catenin dramatically increases $\mathrm{TCF} /$ Lef1 affinity for DNA and induces the recruitment of other transcriptional co-activators, such as p300 and cAMP response element-binding protein (p300/CBP), which synergistically regulate the expression of canonical WNT target genes (Tutter et al., 2001; Mosimann et al., 2009).

\section{WNT non-canonical pathways}

Some Wnt factors can activate downstream signalling independently of $\beta$-catenin, which are collectively known as non-canonical pathways. Two signalling pathways have best been characterised and are denominated Planar Cell Polarity (PCP) pathway and $\mathrm{Ca}^{2+}$-dependent pathway. We will focus our attention on these pathways as they are relevant for the rest of the present review.

\section{PCP pathway}

The non-canonical WNT pathway, also known as Planar Cell Polarity (PCP) pathway because of its role in determining tissue organisation, is a $\beta$-catenin-independent molecular cascade which is triggered by binding of WNT factors, such as WNT5a, to a Fzd/orphan tyrosine kinase Ror2 receptor complex (Mikels and Nusse, 2006) (Fig. 2A). The PCP pathway activates downstream effector molecules small GTPases RhoA, Rac1 and Cdc42, which have several roles in cell physiology (Schlessinger et al., 2009), through Dvl.

Dvl interacts with Daam1 through its PDZ and DEP domains (Gao and Chen, 2010), and they together interact with the Rho guanine nucleotide exchange factor (GEF), thus inducing the formation of a RhoA-GTP complex, which, in turn, activates ROCK kinase. This pathway has been shown to control actomyosin-induced tensional forces within the cytoskeleton and thus the reorganisation and rearrangement of the cytoskeleton (Gao and Chen, 2010).

Dvl can also activate other small GTPases of the Rho family, namely Rac1 and Cdc42. These GTPases stimulate c-JunN-terminal kinase (JNK) and thus control Myosin Light Chain Kinase and promote actin polymerisation, a feature that is required to generate protrusive forces during cell migration (Jaffe and Hall, 2005; Schlessinger et al., 2009).

In the 1980s, Ingber introduced the tensegrity concept to cell biology (Ingber, 1993). According to this model, the cytoskeleton can be envisaged as a pre-stressed network where microfilaments and intermediate filaments 
generate tensional forces that are compensated by stiff microtubules, whose molecular structure allows them to effectively withstand compression, creating a balanced structure under a constant tension (Stamenovic and Coughlin, 1999; Stamenovic et al., 2002; Wang et al., 2002; Ingber, 2003). These principles, originally developed to engineer architectural structures, can effectively prove cell mechanical behaviour. Mechanical stimulation applied to cell membranes can be transferred through the cytoskeleton across the cytoplasm only because its components are under pre-stress (Wang et al., 1993; Wang and Ingber, 1994; Wang et al., 2009b). Pre-stress enables cells to respond to alterations in external forces and changes in the internal pre-stress level may increase or decrease cell sensitivity to mechanical stimuli. Indeed, it has long been known that the shape of a cell can determine its fate (Chen et al., 1997; Smith et al., 2003; Hu and Wang, 2006; Kilian et al.; Wozniak and Chen, 2009; Li et al., 2011). Consistently with these ideas, it has been demonstrated that the isometric tension generated by the activation of RhoA and ROCK is required for osteoblast differentiation (Arnsdorf et al., 2009a; Arnsdorf et al., 2009b). The interplay between cell shape and cell fate is only beginning to be elucidated but it is possible that it will play a major role in future research, in particular for its far-reaching implications in cell responses to surface topography (Habas et al., 2003; Milat and Ng, 2009; Rossol-Allison et al., 2009). More will be said about this topic further below.

\section{WNT/calcium pathway}

Early studies showed that WNT-5 or Rat Frizzled-2 (RFz-

2) overexpression, but not WNT-8 or RFz-1, were able to increase the release frequency of intracellular $\mathrm{Ca}^{2+}$ in zebrafish embryos and activate Protein Kinase C (PKC) in Xenopus (Sheldahl et al., 2003; Freisinger et al., 2008). This evidence allowed the identification of a novel non canonical WNT pathway, mediated by calcium release, which was then called WNT-Ca ${ }^{2+}$-dependent pathway (Fig. 2B).

WNT-Calcium dependent signalling is triggered in response to activation of RFzd-2 receptor or in the presence of WNT-5a/WNT-11 stimulation, without affecting $\beta$-catenin stabilisation. The result is the activation of a wide array of effectors including phospholipase C (PLC), and $\mathrm{Ca}$-sensitive enzymes such as $\mathrm{Ca}$-calmodulin-dependent Protein Kinase II (CamKII) and PKC or calcineurin (Kuhl et al., 2000a; Kuhl et al., 2000b).

The activation of PLC by a G-protein $\beta / \gamma$ dimer mobilises $\mathrm{IP}_{3}$ from the cell membrane. This mediates the release of calcium ions from the endoplasmic reticulum and their intracellular accumulation, which activates $\mathrm{Ca}^{2+}$. sensitive proteins PKC and CamKII.

$\mathrm{WNT} /$ Frizzled-induced calcium release requires Dvl (Kuhl, 2004). Its PDZ and DEP domains are also capable of stimulating the WNT- $\mathrm{Ca}^{2+}$-pathway in a $\mathrm{G}$ protein-independent manner. This suggests that Dvl is either downstream of $\mathrm{G}$ protein or acting in parallel with it (Sheldahl et al., 2003).

\section{The role of Wnt signalling in Embryo Development}

Several authors have demonstrated that the canonical WNT pathway is required in various events of embryo development such as early trophoblast lineage development, blastocyst activation, implantation, chorionallantois fusion, and embryo morphogenesis (Huelsken et al., 2000; Martin and Kimelman, 2009, Sonderegger et al., 2010). Recent evidence has also shown that Wnt pathways are also involved in the control of embryonic stem cell (ES) proliferation and differentiation (Nusse, 2008; Miki et al., 2011; Sokol, 2011), possibly by modulating Oct4, Nanog, and Sox2, which are known to modulate pluripotency (Sato et al., 2004, Anton et al., 2007). Supplementation with Wnt3a has been shown to maintain murine ES (mES) cell pluripotency (Hao et al., 2006; Singla et al., 2006). Stabilisation of $\beta$-catenin through GSK3 $\beta$ inhibitors or GSK3b ablation promoted ES cell self-renewal and expression of stemness-related genes Oct4 and Nanog (Aubert et al., 2002; Sato et al., 2004; Doble et al., 2007). Although Wnt1 overexpression has been reported to attenuate neural differentiation of mES cells (Aubert et al., 2002), some authors reported that Wnt3a stimulated not only human ES cell proliferation, but also differentiation. (Dravid et al., 2005) and conflicting results on the maintenance of stemness and self-renewal by $\beta$-catenin/ TCF have been published (Pereira et al., 2006; Takao et al., 2007; Lyashenko et al., 2011).

\section{The control of bone metabolism by WNT/ $\beta$-catenin signalling}

Beside its role in ES cell physiology, the WNT $\beta$-cateninmediated signalling is a potent player in bone and cartilage metabolism (Krishnan et al., 2006; Chun et al., 2008; Williams et al., 2009). Conditional ablation of $\beta$-catenin from osteochondral progenitors in mice resulted in delayed fracture healing (Huang et al., 2012). Expression of a Col2al-regulated transgene encoding for the $\beta$-catenin and TCF inhibitor ICAT, an 82-amino-acid peptide that binds to the armadillo repeats of $\beta$-catenin and prevents it from binding TCF, delayed formation of secondary ossification centres, and reduced skeletal growth (Chen et al., 2008). Similarly, Osx1-Cre-mediated conditional deletion of $\beta$-catenin in mice disrupted osteoblast differentiation, proving that $\beta$-catenin-mediated transcription is necessary for the commitment of osteochondral progenitors to the osteoblastic lineage and their further differentiation into Osterix-expressing pre-osteoblasts (Rodda and McMahon, 2006). Alterations in bone mass have been observed after LRP5 deletion in rodents or as a consequence of mutations of this gene in humans (Gong et al., 2001; Boyden et al., 2002; Kato et al., 2002; Babij et al., 2003; Holmen et al., 2004; Kokubu et al., 2004; Sawakami et al., 2006; Joeng et al., 2011). Since $\beta$-catenin is also a membrane component, it is not surprising that the transmembrane protein $\mathrm{N}$-cadherin, a component of cell-to-cell junctions, can act as an inhibitor of $\mathrm{WNT} / \beta$-catenin signalling by binding and sequestering LRP5 and axin and thus 


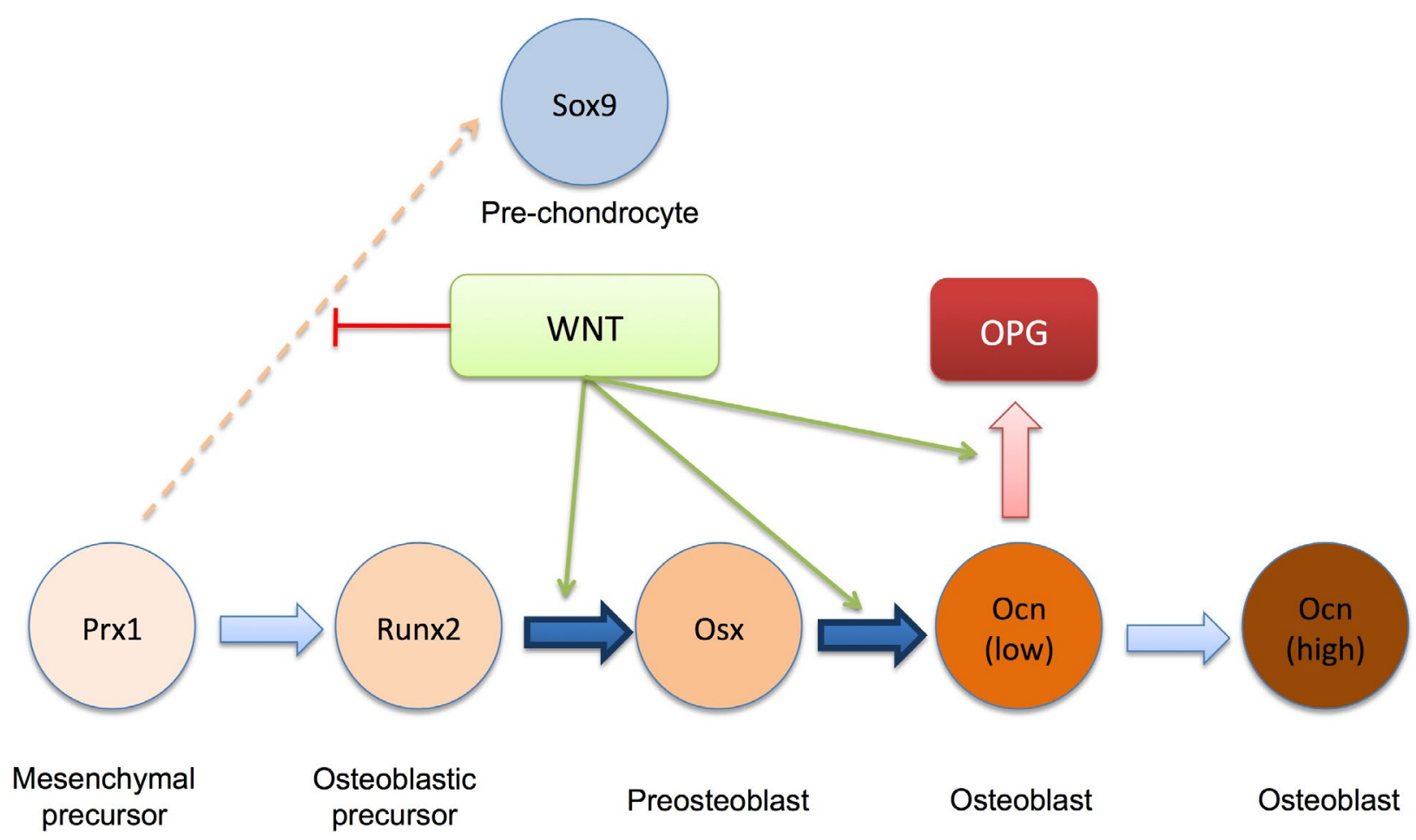

Fig. 3. Scheme showing WNT signalling effects on osteoblastic differentiation. The expression of specific promoters Prx1, Runx2, Osterix (Osx), Osteocalcin (OCN) at low or at high levels is used to label progressive stages of differentiation along the lineage. Canonical, and in part non-canonical, WNT pathways promote commitment to the osteoblastic lineage and expression of osteoprotegerin (OPG), while inhibiting the progression of osteochondral precursors to the chondrogenic fate (modified from Rodda and McMahon, 2006).

reducing bone mass in mice (Hay et al., 2009). Taken together, the available evidence in the literature indicates that $\beta$-catenin can act as a molecular switch determining the differentiation lineage that mesenchymal precursors commit to, promoting osteoblast differentiation, and thus bone formation, over alternative cell fates, such as chondrocytes or adipocytes (Hill et al., 2005; Kennel and McDougal, 2005; Rodda and McMahon, 2006) (Fig. 3). Interestingly, inhibition of $\beta$-catenin by Chibby (Cby), an evolutionarily-conserved $14.5 \mathrm{kD}$ competitive antagonist (Takemaru et al., 2003) or block of canonical signalling by non-canonical Wnt5b factor is necessary for adipocytic differentiation (Li et al., 2007; van Tienen et al., 2009). Conversely, $\beta$-catenin stabilisation has been proven to suppress adipocyte differentiation (Cho et al., 2008). Moreover, $\beta$-catenin has been proven to act on mature bone and regulate bone remodelling by inducing osteoprotegerin (OPG) expression (Glass et al., 2005), the decoy receptor of Receptor Activator for Nuclear Factor kB Ligand (RANKL), which is required for osteoclast differentiation. Non-canonical signalling pathways are likely to play an important role too, as recently demonstrated by Chang et al. who showed that overexpression of WNT-4 activates a $\beta$-catenin-independent signalling cascade and induce osteoblastic differentiation of periodontal ligamentderived MSCs, thus enhancing bone regeneration in periodontal and calvaria bone defect models (Chang et al., 2007). Although ablation studies have repeatedly shown that $\beta$-catenin-mediated signalling is required for osteoblastogenesis and bone formation (Hill et al., 2005; Rodda and McMahon, 2006), activation of the canonical Wnt pathway by $\beta$-catenin overexpression has yielded conflicting results on both osteoblast differentiation in vitro (Fukuda et al., 2010) and bone formation in vivo (Hill et al., 2005), suggesting that a more complex modulation of the signal and activation of parallel pathways are required for correct bone accrual.

\section{The effects of titanium topography on WNT signalling pathway}

The topography of titanium surfaces influences the biological responses of cells, of surrounding tissues, hence affecting implant osseointegration (Boyan et al., 2002; Linez-Bataillon et al., 2002; Ramires et al., 2002; Buser et al., 2004; Lossdorfer et al., 2004; Schneider et al., 2004; Isa et al., 2006; Germanier et al., 2006). Although this phenomenon has long been known, the molecular mechanisms responsible for the effect of surface roughness on cell function are still poorly understood.

It is known that osteoblasts growing on microstructured Ti surfaces produce local factors that regulate bone formation as well as bone remodelling, including the expression of RANK ligand decoy receptor osteoprotegerin (OPG), under the control of a2 $\beta 1$ integrins (Schwartz et al., 2009). Even nanoscale topographies can alter cell gene expression (Dalby et al., 2008). 
The gene expression profile associated with the early response biological processes during the osseointegration of implants with rough surface is characterised by an over-representation of genes associated with proliferation and immuno-inflammatory response, and, at a later stage, of genes associated with skeletogenesis and angiogenesis (Ivanovski et al., 2011). Moreover, in agreement with these findings, the in vivo gene expression profile of guided bone regeneration around a micro-rough titanium surface showed a profound up-regulation of skeletogenesis-related genes on sand-blasted and acid etched (SLA) surface, accompanied by an increase in angiogenesis-associated gene expression (Donos et al., 2011b).

In vivo and in vitro whole genome analysis (Wall et al., 2009; Donos et al., 2011b; Ivanovski et al., 2011) identified WNT signalling as the predominant signalling pathway differentially regulated by surface features such as topography and wettability, and it is currently deemed the most important pathway in the regulation of cell differentiation in response to implant surfaces. WNT pathways are activated on rough surface topography through over expression of WNT ligands such as WNT2b, WNT8b, WNT10a and of LRP5 receptor, thereby resulting in enhanced cell differentiation on rough SLA surface as confirmed by enhanced expression of osteoblast specific genes alkaline phosphatase (ALP), osteocalcin (OCN), OPG, Runx 2 and TGF- $\beta 1$ (Olivares-Navarrete et al., 2011a).

The involvement of WNT signalling on modulation of cell behaviour on rough titanium surface was also proven by the role of WNT signalling modulators on osteoblast differentiation on microstructured titanium surfaces. A large number of antagonists can modulate WNT signalling. These include the Dickkopf (Dkk) family, WNT inhibitory factor (WIF), soluble Frizzled-related proteins (sFRP), and Cerberus and Sclerostin families. Both Dickkopf-1 (Dkk1) and Dickkopf-2 (Dkk2) inhibit the WNT signalling pathway by binding to LRP5/6 and preventing formation of the WNT- Fzd-LRP complex (Qiang et al., 2008a; OlivaresNavarrete et al., 2010a). Olivares-Navarrete et al. recently demonstrated that expression and activity of Dkk1 and Dkk2 was modulated in MSCs, HOBs and MG63 cells on Ti surfaces with rough microstructure (Olivares-Navarrete et al., 2010a). Moreover, Dkk1 silencing increased the expression of differentiation markers OCN and OPG on smooth substrates but not on rough Ti. Silencing Dkk2 reduced stimulatory effects of SLA and modSLA on osteoblast differentiation because it reduced production of autocrine regulators of osteoblasts differentiation (TGF $\beta 1$ ) and osteoclast activity (OPG, TGF $\beta 1$ ). Dkk1 and 2 also prevented MSC differentiation, thus promoting an undifferentiated stem cell phenotype (Olivares-Navarrete et al., 2010a).

Data from our group showed that more $\beta$-catenin translocated to the nucleus in cells on SLA surfaces after stimulation with WNT3a and stimulation of the $\beta$-catenin/ TCF signalling was accountable for at least part of the effects of surface on cell differentiation (Galli et al., 2010). Rough surfaces enhanced the WNT3a-induced expression of $\beta$-catenin target genes ALP, OPG, Wisp2, Connexin 43 (Cx43) and Cyclooxygenase 2 (Cox-2). The induction of a $\beta$-catenin mutant form (S33Y) that could not be phosphorylated by the destruction complex and thus be degraded reversed the effects of surface topography on $\beta$-catenin-mediated transcription, suggesting that surface topography may have a permissive effect on WNT canonical signalling by acting on $\beta$-catenin degradation (Galli et al., 2010).

Interestingly, surface topography can affect other $\beta$-catenin-dependent molecular cascades, such as the FoxO pathway, which is responsible for cell defences against oxidative stress. We showed that FoxO $/ \beta$-catenin signalling was elevated in cells on rough surfaces, as demonstrated by increased FoxO-Luc activity and higher mRNA levels for FoxO-target genes MnSOD, Catalase, GADD45 (Galli et al., 2011). Although the molecular basis of the higher activity of FoxO-mediated pathway on rough surfaces is still to be investigated, it is possible that the same mechanisms underlie the activation of these $\beta$-catenindependent pathways, possibly a higher availability of free cytosolic $\beta$-catenin. A reduced sequestering of $\beta$-catenin by membrane-associated Cadherins, due to reduced cellto-cell junctions and increased cell spacing on rough and irregular surfaces, may play a role in this phenomenon.

Moreover, it has been demonstrated that both ALP activity and OCN in MG63 and hMSC cells increased on titanium surfaces in the presence of exogenous non canonical WNT5a, reaching highest levels on rough surfaces, whereas WNT3a treatment failed to affect osteoblastic gene expression (Olivares-Navarrete et al., 2011a; Olivares-Navarrete et al., 2011b). Indeed, wholegenome analysis revealed that the osteogenic mediator WNT5a was up-regulated on rough titanium (Wall et al., 2009). This would support the idea that non-canonical WNT pathways may play an important role in differentiation of cells on microstructured titanium surfaces alongside with the canonical cascade. Although it is not clear which non-canonical pathways are modulated by surface topography, the PCP pathway seems to be involved in the regulation of cell orientation on microstructured implant surfaces (Calzado-Martin et al., 2011). Moreover, Wnt5a upregulation may indicate that Ca-dependent cascade is activated on rough surfaces, although this factor has been shown to can exert its action through alternative cascades such as by activating RhoA in mechanical stimulation of osteoblasts (Arnsdorf et al., 2009a; Arnsdorf et al., 2009b). It is important to remember that even well-established canonical factors such as Wnt3a can activate parallel signalling pathways that have been shown to affect bone formation (Tu et al., 2007).

In recent years, in addition to topographical changes, chemical modification of titanium has become a focus of attempts to positively influence the process of osseointegration.

Hyperhydrophilic titanium surfaces surfaces (modSLA), obtained by rinsing under $\mathrm{N}_{2}$ protection and storage in an isotonic $\mathrm{NaCl}$ solution (Rupp et al., 2006), maintain the topography of the original surface, but exhibit increased 
surface free energy and lower water contact angles $\left(0^{\circ}\right.$ compared to $139.98^{\circ}$ for conventional SLA surfaces) (Schwarz et al., 2007; Olivares-Navarrete et al., 2010b).

Higher surface energy of titanium surfaces has been shown to enhance cell adhesion in the early stages of cell response and increase the expression of Focal Adhesion Kinase (Lai et al., 2010,). Donos and colleagues, using the genome-wide analysis, studied the gene expression profile of osseointegration associated with a moderately rough (SLA) and a hydrophilic/moderately rough surface (modSLA) in a human model. They inserted titanium endosseous implants with different topography in the retromolar area of volunteer subjects and observed upregulation of osteogenesis- and angiogenesis-associated gene expression on modSLA surfaces (Donos et al., 2011a) over a time of up to 2 weeks. Several other genes relevant to bone maturation, such as OCN, BMP2, CTNNA1, FZD6 and effectors of the TGF $\beta$-BMP signalling cascade were significantly up-regulated on modSLA samples (VlacicZischke et al., 2011).

It is important to point out that, in contrast to the available general literature on cell responses to implant surfaces, a limited array of surface treatments have been used as experimental models for the regulation of Wnt signalling by implant surfaces, and no study has investigated whether the isotropic or anisotropic features of the surface or other geometric characteristics of the implant surface, which have been shown to play a relevant role in affecting cell activity (Bigerelle et al., 2002; Bigerelle et $a l ., 2011$ ) can actually influence this particular pathway.

\section{Topography, cytoskeleton and cell differentiation}

The relationship between cell shape and cell fate has long been subject of speculation and research. It is known that cell spreading leads to higher cytoskeletal tension and differential expression of the small GTPase RhoA and its downstream effector Rho-associated protein kinase (ROCK) (McBeath et al., 2004). The activation of Rho and ROCK plays a significant role in regulating cytoskeletal dynamics and generates isometric tension within the cytoskeleton, acting as a switch for osteoblastogenesis (Kanno et al., 2007; Salasznyk et al., 2007; Kearney et al., 2010). Oh and co-workers studied the differentiation of MSCs on titanium oxide nanotubes of different size and found that increased cell spreading on $70 \mathrm{~nm}$ nanotubes was associated to increased osteogenesis. It is likely that elongated morphology caused cellular cytoskeletal tension in hMSCs cultured on 70 to $100 \mathrm{~nm}$ diameter nanotubes as compared with cells growing on a flat surface (Oh et al., 2009).

The hypothesis that local shape promotes cell contractility and tension, which in turn enhances differentiation along the osteoblastic lineage was confirmed in a recent work by Kilian et al., who observed that cell shapes promoting increased contractility (star-like shapes) led to higher expression of osteoblast specific genes (Kilian et al., 2010). In contrast, cell shapes that required low contractility (flower-like shapes) promoted cell differentiation along the adipocytic lineage.
Moreover, treatment with cytoskeleton-disrupting agents decreased cytoskeletal contractility and thus inhibited osteoblastogenesis. Gene expression analysis by DNA microarrays revealed higher levels of transcript for proosteogenic WNT-associated factors (including downstream effectors RhoA and ROCK) in star-shaped cells, highlighting the importance of adhesion and a highly contractile state for bone cell formation (Kilian et al., 2010). Furthermore, it has been reported that matrix mechanical characteristics, i.e. stiffness, affect stem cell and osteoblast differentiation (Engler et al., 2006; Chatterjee et al., 2010; Pek et al., 2010) and that lineage commitment requires myosin-mediated cell contractility (Engler et al., 2006).

Consistently with these findings, RhoA has also been demonstrated to be required to activate PI3K and MAPK signalling in osteoblastic MC3T3 cells under mechanical stimulation (Hamamura et al., 2012), and integrin-mediated mechanical stimulation of Focal Adhesion Kinase (FAK) has long been recognised as necessary for mechanical transduction in osteoblastic cells (Ponik and Pavalko, 2004; Boutahar et al., 2004; Young et al., 2009; Wang et al., 2011; Young et al., 2011). Biggs et al. demonstrated that surface topography directly affects formation of adhesion complexes (Biggs et al., 2009), and this could contribute to modulating the mechanical stimulation of cells on implant substrates. Although molecular pathways by which cell shape and cytoskeletal mechanics drive cell commitment are still uncertain, it becomes evident that topology surface cues can be used to enhance and rationally control differentiation specific signalling, thereby accelerating guided differentiation in engineered scaffolds.

\section{Perspectives}

Based on the important role of WNT signalling in osteogenesis, it has been proposed that stimulation of WNT pathways may improve implant osseointegration. To this purpose, WNT growth factors seem like attractive candidates to stimulate bone formation.

A recent paper by Popelut et al. (Popelut et al., 2010) showed that liposomal WNT3a transiently enhanced the physiological WNT response that occurs after fractures and implant placement. Peri-implant tissues treated with liposomal WNT3a showed a significant up-regulation of Collagen type I and ALP. Moreover, sites treated with liposomal WNT3a exhibited more bone-to-implant contact surface, with mineralised osteoid matrix in close proximity to the implant surface, thus demonstrating that transient exposure to WNT3a induces peri-implant cells to rapidly commit to an osteogenic lineage.

Stimulation of WNT signalling by strontium induces proliferation and differentiation of murine osteoblasts (Fromigue et al., 2010). The authors showed that strontium ranelate (SnRel) increased WNT3a and WNT5a expression as well as $\beta$-catenin transcriptional activity in osteoblasts. Yang et al. demonstrated that the activation of WNT pathway, which was induced by strontium, not only promoted the in vitro differentiation of both murine osteoblasts and human MSCs, but also significantly 
enhanced in vivo bone formation (Yang et al., 2011). Strontium-containing hydroxyapatite scaffolds enhanced the accumulation of extracellular matrix in the bone defect and enhanced $\beta$-catenin expression in vivo (Yang et al., 2011). Although preliminary, their important work suggests that this approach may be proposed to promote implant osseointegration.

Lithium chloride was recently shown to activate the canonical WNT signalling pathway, both in vitro and in vivo. $\mathrm{LiCl}$ inhibits glycogen synthase kinase $3 \beta$ (GSK3 $\beta$ ), an enzyme that phosphorylates $\beta$-catenin in the cytoplasm targeting it for ubiquitination and degradation. It also activates WNT signalling independently of WNT receptor, resulting in significantly increased bone formation and bone mass in rodents (Clement-Lacroix et al., 2005). Wang and colleagues used the electrolytic deposition of lithium into calcium phosphate coatings and showed that both attachment and early proliferation of MG63 cells on these hybrid coatings were enhanced and that, though lithium incorporation interferes with calcium phosphate deposition, it ameliorates coating biocompatibility (Wang et al., 2009a).

Although much evidence points at WNT stimulation as a viable approach to induce bone formation, some studies represent an important warning that caution must be exerted when modulating this signal pathway. A recent work by Kim et al. suggests that up-regulation of WNT canonical signalling alone, though required for bone healing, may not be sufficient for mature bone formation (Kim et al., 2007) and that, albeit necessary for Osterix expression, stabilisation of $\beta$-catenin inhibits Sox 9 and Runx2 expression, and thus bone formation (Hill et al., 2005). In vitro studies showed that activation of the canonical WNT pathway by WNT-1 or WNT-3a can actually suppress osteogenic differentiation in mesenchymal stem cells (MSC) (Boland et al., 2004; De Boer et al., 2004). Interestingly, ablation of any Wnt factor has not duplicated the arrest in osteoblastogenesis observed with LRP5 or $\beta$-catenin deletion, suggesting that various Wnts could act redundantly in this process and most likely act in a coordinated fashion, where both timing and expression patterns contribute to lead mesenchymal cells along the osteoblastic lineage (Hill et al., 2005). Consistently with these studies, the WNT competitive antagonist soluble Frizzled Receptor Protein 3 (sFRP3) increased production of the osteoblastic marker osteocalcin in the osteoblastic MC3T3 cell line (Chung et al., 2004). Other inhibitors of WNT canonical signalling, Dkk1 and Dkk2, appeared to be required for full osteoblastic differentiation (Li et al., 2005; van der Horst et al., 2005), although Dkk1 is also known to inhibit osteoblast function in myeloma-induced bone lesions (Qiang et al., 2008b; Heath et al., 2009) and, conversely, WNT3a signalling within bone can inhibit the growth of this tumour (Qiang et al., 2008c). This amount of data shows that WNT proteins exert a very complex modulation of osteoblast differentiation, through temporally distinct expression patterns (Zhang et al., 2008) in different physiological situations, about which little is known and that future studies will have the task to explore in detail.

\section{Conclusions}

WNT pathways have been proven to regulate osteoblast commitment and control bone formation and remodelling. Recent literature has shown that implant topographical characteristics or topography can modulate both canonical and non-canonical pathways in mesenchymal cells. Based on the available data, surface control of WNT signalling appears as one of the prominent mechanisms by which implant surfaces can direct cell commitment and differentiation. Control of this signalling pathway appears therefore as a promising approach to improve implant osseointegration and possibly clinical success, and future studies will have to thoroughly explore the molecular mechanisms through which surface topography can affect WNT signalling in cells and how to regulate the activation of this pathway to enhance osteogenesis.

\section{References}

Angers S, Moon RT (2009) Proximal events in Wnt signal transduction. Nat Rev Mol Cell Biol 10: 468-477.

Anselme K (2011) Biomaterials and interface with bone. Osteoporos Int 22: 2037-2042.

Anselme K, Ponche A, Bigerelle M (2010) Relative influence of surface topography and surface chemistry on cell response to bone implant materials. Part 2: biological aspects. Proc Inst Mech Eng H 224: 1487-1507.

Anton R, Kestler HA, Kuhl M (2007). Beta-catenin signaling contributes to stemness and regulates early differentiation in murine embryonic stem cells. FEBS Lett 581: 5247-5254.

Arce L, Yokoyama NN, Waterman ML (2006) Diversity of LEF/TCF action in development and disease. Oncogene 25: 7492-7504.

Arcelli D, Palmieri A, Pezzetti F, Brunelli G, Zollino I, Carinci F (2007) Genetic effects of a titanium surface on osteoblasts: a meta-analysis. J Oral Sci 49: 299-309.

Arnsdorf EJ, Tummala P, Jacobs CR (2009a) Noncanonical Wnt signaling and $\mathrm{N}$-cadherin related betacatenin signaling play a role in mechanically induced osteogenic cell fate. PLoS One 4: e5388.

Arnsdorf EJ, Tummala P, Kwon RY, Jacobs CR (2009b) Mechanically induced osteogenic differentiation - the role of RhoA, ROCKII and cytoskeletal dynamics. J Cell Sci 122: 546-553.

Aubert J, Dunstan H, Chambers I, Smith A (2002) Functional gene screening in embryonic stem cells implicates Wnt antagonism in neural differentiation. Nature Biotechnol 20: 1240-1245.

Axelrod JD, Miller JR, Shulman JM, Moon RT, Perrimon N (1998) Differential recruitment of Dishevelled provides signaling specificity in the planar cell polarity and Wingless signaling pathways. Genes Dev 12: 2610-2622.

Babij P, Zhao W, Small C, Kharode Y, Yaworsky PJ, Bouxsein ML, Reddy PS, Bodine PV, Robinson JA, Bhat B, Marzolf J, Moran RA, Bex F (2003) High bone mass in mice expressing a mutant LRP5 gene. J Bone Miner Res 18: $960-974$. 
Bernatik O, Ganji RS, Dijksterhuis JP, Konik P, Cervenka I, Polonio T, Krejci P, Schulte G, Bryja V (2011) Sequential activation and inactivation of Dishevelled in the Wnt/beta-catenin pathway by casein kinases. J Biol Chem 286: 10396-10410.

Bigerelle M, Anselme K, Noël B, Ruderman I, Hardouin P, Iost A (2002) Improvement in the morphology of Ti-based surfaces: a new process to increase in vitro human osteoblast response. Biomaterials 23: 1563-1577.

Bigerelle M, Giljean S, Anselme K (2011) Existence of a typical threshold in the response of human mesenchymal stem cells to a peak and valley topography. Acta Biomater 7: 3302-3311.

Biggs MJ, Richards RG, Gadegaard N, McMurray RJ, Affrossman S, Wilkinson CD, Oreffo RO, Dalby MJ (2009) Interactions with nanoscale topography: adhesion quantification and signal transduction in cells of osteogenic and multipotent lineage. J Biomed Mater Res A 91: 195208.

Boland GM, Perkins G, Hall DJ, Tuan RS (2004) Wnt 3a promotes proliferation and suppresses osteogenic differentiation of adult human mesenchymal stem cells. J Cell Biochem 93: 1210-1230.

Bornstein MM, Valderrama P, Jones AA, Wilson TG, Seibl R, Cochran DL (2008) Bone apposition around two different sandblasted and acid-etched titanium implant surfaces: a histomorphometric study in canine mandibles. Clin Oral Implants Res 19: 233-241.

Boutahar N, Guignandon A, Vico L, Lafage-Proust MH (2004) Mechanical strain on osteoblasts activates autophosphorylation of focal adhesion kinase and prolinerich tyrosine kinase 2 tyrosine sites involved in ERK activation. J Biol Chem 279: 30588-30599.

Boutros M, Mlodzik M (1999) Dishevelled: at the crossroads of divergent intracellular signaling pathways. Mech Dev 83: 27-37.

Boyan BD, Bonewald LF, Paschalis EP, Lohmann CH, Rosser J, Cochran DL, Dean DD, Schwartz Z, Boskey AL (2002) Osteoblast mediated mineral deposition in culture is dependent on surface mictotopography. Calcif Tiss Int 71: 519-529.

Boyden LM, Mao J, Belsky J, Mitzner L, Farhi A, Mitnick MA, Wu D, Insogna K, Lifton RP (2002) High bone density due to a mutation in LDL-receptor-related protein 5. N Engl J Med 346: 1513-1521.

Brånemark PI (1983) Osseointegration and its experimental background. J Prosthet Dent 50: 399-410.

Buser D, Broggini N, Wieland M, Schenk RK, Denzer AJ, Cochran DL, Hoffmann B, Lussi A, Steinemann SG (2004) Enhanced bone apposition to a chemically modified SLA titanium surface. J Dent Res 83: 529-533.

Cadigan KM, Nusse R (1997) Wnt signaling: a common theme in animal development. Genes Dev 11: 3286-3305.

Calzado-Martín A, Méndez-Vilas A, Multigner M, Saldaña L, González-Carrasco JL, González-Martín ML, Vilaboa N (2011) On the role of RhoA/ROCK signaling in contact guidance of bone-forming cells on anisotropic Ti6Al4V surfaces. Acta Biomater 7:1890-1901.

Cervenka I, Wolf J, Masek J, Krejci P, Wilcox WR, Kozubik A, Schulte G, Gutkind JS, Bryja V (2011) Mitogen-activated protein kinases promote WNT/beta- catenin signaling via phosphorylation of LRP6. Mol Cell Biol 31: 179-189.

Chang J, Sonoyama W, Wang Z, Jin Q, Zhang C, Krebsbach PH, Giannobile W, Shi S, Wang CY (2007) Noncanonical Wnt-4 signaling enhances bone regeneration of mesenchymal stem cells in craniofacial defects through activation of p38 MAPK. J Biol Chem 282: 30938-30948.

Chatterjee K, Lin-Gibson S, Wallace WE, Parekh SH, Lee YJ, Cicerone MT, Young MF, Simon CG Jr (2010) The effect of 3D hydrogel scaffold modulus on osteoblast differentiation and mineralization revealed by combinatorial screening. Biomaterials 31: 5051-5062.

Chen CS, Mrksich M, Huang S, Whitesides GM, Ingber DE (1997) Geometric control of cell life and death. Science 276: $1425-1428$.

Chen M, Zhu M, Awad H, Li TF, Sheu TJ, Boyce BF, Chen D, O'Keefe RJ (2008) Inhibition of beta-catenin signaling causes defects in postnatal cartilage development. J Cell Sci 121: 1455-1465.

Chia IV, Costantini F (2005) Mouse axin and axin2/ conductin proteins are functionally equivalent in vivo. Mol Cell Biol 25: 4371-4376.

Cho M, Park S, Gwak J, Kim DE, Yea SS, Shin JG, Oh S (2008) Bisindoylmaleimide I suppresses adipocyte differentiation through stabilization of intracellular betacatenin protein. Biochem Biophys Res Commun 367: 195-200.

Chun JS, Oh H, Yang S, Park M (2008) Wnt signaling in cartilage development and degeneration. BMB Rep 41: 485-494.

Chung YS, Baylink DJ, Srivastava AK, Amaar Y, Tapia B, Kasukawa Y, Mohan S (2004) Effects of secreted frizzled-related protein 3 on osteoblasts in vitro. J Bone Miner Res 19: 1395-1402.

Clement-Lacroix P, Ai M, Morvan F, Roman-Roman S, Vayssiere B, Belleville C, Estrera K, Warman ML, Baron R, Rawadi G (2005) Lrp5-independent activation of Wnt signaling by lithium chloride increases bone formation and bone mass in mice. Proc Natl Acad Sci USA 102: 1740617411.

Clevers H (2006) Wnt/beta-catenin signaling in development and disease. Cell 127: 469-480.

Coelho PG, Freire JN, Granato R, Marin C, Bonfante EA, Gil JN, Chuang SK, Suzuki M (2011) Bone mineral apposition rates at early implantation times around differently prepared titanium surfaces: a study in beagle dogs. Int J Oral Maxillofac Implants 26: 63-69.

Dalby MJ, Andar A, Nag A, Affrossman S, Tare R, McFarlane S, Oreffo RO (2008) Genomic expression of mesenchymal stem cells to altered nanoscale topographies. J R Soc Interface.5: 1055-1065.

De Boer J, Wang HJ, Van Blitterswijk C (2004) Effects of Wnt signaling on proliferation and differentiation of human mesenchymal stem cells. Tissue Eng 10: 393-401.

Doble BW, Patel S, Wood GA, Kockeritz LK, Woodgett JR (2007) Functional redundancy of GSK-3alpha and GSK-3beta in Wnt/beta-catenin signaling shown by using an allelic series of embryonic stem cell lines. Dev Cell 12: 957-971.

Donos N, Hamlet S, Lang NP, Salvi GE, Huynh-Ba G, Bosshardt DD, Ivanovski S (2011a) Gene expression 
profile of osseointegration of a hydrophilic compared with a hydrophobic microrough implant surface. Clin Oral Implants Res 22: 365-372.

Donos N, Retzepi M, Wall I, Hamlet S, Ivanovski S (2011b) In vivo gene expression profile of guided bone regeneration associated with a microrough titanium surface. Clin Oral Implants Res 22: 390-398.

Dravid G, Ye Z, Hammond H, Chen G, Pyle A, Donovan P, Yu X, Cheng L (2005) Defining the role of Wnt/beta-catenin signaling in the survival, proliferation, and self-renewal of human embryonic stem cells. Stem Cells 23: 1489-1501.

Engler AJ, Sen S, Sweeney HL, Discher DE (2006) Matrix elasticity directs stem cell lineage specification. Cell 126: 677-689.

Force T, Woodgett JR (2009) Unique and overlapping functions of GSK-3 isoforms in cell differentiation and proliferation and cardiovascular development. J Biol Chem 284: 9643-9647.

Freisinger CM, Schneider I, Westfall TA, Slusarski DC (2008) Calcium dynamics integrated into signalling pathways that influence vertebrate axial patterning. Philos Trans R Soc Lond B Biol Sci 363: 1377-1385.

Fromigue O, Hay E, Barbara A, Marie PJ (2010) Essential role of nuclear factor of activated T cells (NFAT)mediated Wnt signaling in osteoblast differentiation induced by strontium ranelate. J Biol Chem 285: 2525125258.

Fukuda T, Kokabu S, Ohte S, Sasanuma H, Kanomata K, Yoneyama K, Kato H, Akita M, Oda H, Katagiri T (2010) Canonical Wnts and BMPs cooperatively induce osteoblastic differentiation through a GSK3beta-dependent and beta-catenin-independent mechanism. Differentiation. 80: $46-52$.

Gahlert M, Gudehus T, Eichhorn S, Steinhauser E, Kniha H, Erhardt W (2007) Biomechanical and histomorphometric comparison between zirconia implants with varying surface textures and a titanium implant in the maxilla of miniature pigs. Clin Oral Implants Res 18: 662-668.

Galli C, Passeri G, Ravanetti F, Elezi E, Pedrazzoni M, Macaluso GM (2010) Rough surface topography enhances the activation of Wnt/beta-catenin signaling in mesenchymal cells. J Biomed Mater Res A 95: 682-690.

Galli C, Macaluso GM, Piemontese M, Passeri G (2011) Titanium topography controls FoxO/beta-catenin signaling. J Dent Res 90: 360-364.

Gao C, Chen YG (2010) Dishevelled: The hub of Wnt signaling. Cell Signal 22: 717-727.

Germanier Y, Tosatti S, Broggini N, Textor M, Buser D (2006) Enhanced bone apposition around biofunctionalized sandblasted and acid-etched titanium implant surfaces. A histomorphometric study in miniature pigs. Clin Oral Implants Res 17: 251-257.

Glass DA 2nd, Bialek P, Ahn JD, Starbuck M, Patel MS, Clevers H, Taketo MM, Long F, McMahon AP, Lang RA, Karsenty G (2005) Canonical Wnt signaling in differentiated osteoblasts controls osteoclast differentiation. Dev Cell 8: 751-764.
Gong Y, Slee RB, Fukai N, Rawadi G, Roman-Roman $\mathrm{S}$, Reginato AM, Wang H, Cundy T, Glorieux FH, Lev D, Zacharin M, Oexle K, Marcelino J, Suwairi W, Heeger S, Sabatakos G, Apte S, Adkins WN, Allgrove J, ArslanKirchner M, Batch JA, Beighton P, Black GC, Boles RG, Boon LM, Borrone C, Brunner HG, Carle GF, Dallapiccola B, De Paepe A, Floege B, Halfhide ML, Hall B, Hennekam RC, Hirose T, Jans A, Juppner H, Kim CA, Keppler-Noreuil K, Kohlschuetter A, LaCombe D, Lambert M, Lemyre E, Letteboer T, Peltonen L, Ramesar RS, Romanengo M, Somer H, Steichen-Gersdorf E, Steinmann B, Sullivan B, Superti-Furga A, Swoboda W, van den Boogaard MJ, Van Hul W, Vikkula M, Votruba M, Zabel B, Garcia T, Baron R, Olsen BR, Warman ML (2001) LDL receptorrelated protein 5 (LRP5) affects bone accrual and eye development. Cell 107: 513-523.

Habas R, Dawid IB, He X (2003) Coactivation of Rac and Rho by Wnt/Frizzled signaling is required for vertebrate gastrulation. Genes Dev 17: 295-309.

Hamamura K, Swarnkar G, Tanjung N, Cho E, Li J, Na S, Yokota H (2012) RhoA-mediated signaling in mechanotransduction of osteoblasts. Connect Tissue Res, in press

Hao J, Li TG, Qi X, Zhao DF, Zhao GQ.(2006). WNT/ beta-catenin pathway up-regulates Stat3 and converges on LIF to prevent differentiation of mouse embryonic stem cells. Dev Biol 290: 81-91.

Hay E, Laplantine E, Geoffroy V, Frain M, Kohler T, Muller R, Marie PJ (2009) N-cadherin interacts with axin and LRP5 to negatively regulate $\mathrm{Wnt} /$ beta-catenin signaling, osteoblast function, and bone formation. Mol Cell Biol 29: 953-964.

Heath DJ, Chantry AD, Buckle CH, Coulton L, Shaughnessy JD Jr, Evans HR, Snowden JA, Stover DR, Vanderkerken K, Croucher PI (2009) Inhibiting Dickkopf-1 (Dkk1) removes suppression of bone formation and prevents the development of osteolytic bone disease in multiple myeloma. J Bone Miner Res 24: 425-436.

Hill TP, Später D, Taketo MM, Birchmeier W, Hartmann C (2005) Canonical Wnt/beta-catenin signaling prevents osteoblasts from differentiating into chondrocytes. Dev Cell 8: 727-738.

Hoeppner LH, Secreto FJ, Westendorf JJ (2009) Wnt signaling as a therapeutic target for bone diseases. Expert Opin Ther Targets 13: 485-496.

Holmen SL, Giambernardi TA, Zylstra CR, BucknerBerghuis BD, Resau JH, Hess JF, Glatt V, Bouxsein ML, Ai M, Warman ML, Williams BO (2004) Decreased BMD and limb deformities in mice carrying mutations in both Lrp5 and Lrp6. J Bone Miner Res 19: 2033-2040.

$\mathrm{Hu}$ S, Wang N (2006) Control of stress propagation in the cytoplasm by prestress and loading frequency. Mol Cell Biomech 3: 49-60.

Huang Y, Zhang X, Du K, Yang F, Shi Y, Huang J, Tang T, Chen D, Dai K (2012) Inhibition of beta-catenin signaling in chondrocytes induces delayed fracture healing in mice. J Orthop Res, in press.

Huelsken J, Vogel R, Brinkmann V, Erdmann B, Birchmeier C, Birchmeier W (2000) Requirement for 
beta-catenin in anterior-posterior axis formation in mice. J Cell Biol 148: 567-578.

Ingber DE (1993) Cellular tensegrity: defining new rules of biological design that govern the cytoskeleton. J Cell Sci. 104: 613-627.

Ingber DE (2003) Tensegrity I. Cell structure and hierarchical systems biology. J Cell Sci 116: 1157-1173.

Isa ZM, Schneider GB, Zaharias R, Seabold D, Stanford CM (2006) Effects of fluoride-modified titanium surfaces on osteoblast proliferation and gene expression. Int J Oral Maxillofac Implants 21: 203-211.

Ivanovski S, Hamlet S, Salvi GE, Huynh-Ba G, Bosshardt DD, Lang NP, Donos N (2011) Transcriptional profiling of osseointegration in humans. Clin Oral Implants Res 22: 373-381.

Jaffe AB, Hall A (2005) Rho GTPases: biochemistry and biology. Annu Rev Cell Dev Biol 21: 247-269.

Joeng KS, Schumacher CA, Zylstra-Diegel CR, Long F, Williams BO (2011) Lrp5 and Lrp6 redundantly control skeletal development in the mouse embryo. Dev Biol 359: 222-229.

Kämmerer PW, Gabriel M, Al-Nawas B, Scholz T, Kirchmaier CM, Klein MO (2012) Early implant healing: promotion of platelet activation and cytokine release by topographical, chemical and biomimetical titanium surface modifications in vitro. Clin Oral Implants Res 23: 504-510.

Kanno T, Takahashi T, Tsujisawa T, Ariyoshi W, Nishihara T (2007) Mechanical stress-mediated Runx2 activation is dependent on Ras/ERK1/2 MAPK signaling in osteoblasts. J Cell Biochem 101: 1266-1277.

Kato M, Patel MS, Levasseur R, Lobov I, Chang BH, Glass DA 2nd, Hartmann C, Li L, Hwang TH, Brayton CF, Lang RA, Karsenty G, Chan L (2002) Cbfa1-independent decrease in osteoblast proliferation, osteopenia, and persistent embryonic eye vascularization in mice deficient in Lrp5, a Wnt coreceptor. J Cell Biol 157: 303-314.

Katoh Y, Katoh M (2005) Identification and characterization of rat Wnt1 and Wnt10b genes in silico. Int J Oncol 26: 841-845.

Kearney EM, Farrell E, Prendergast PJ, Campbell VA (2010) Tensile strain as a regulator of mesenchymal stem cell osteogenesis. Ann Biomed Eng 38:1767-1779.

Keller JC, Schneider GB, Stanford CM, Kellogg B (2003) Effects of implant microtopography on osteoblast cell attachment. Implant Dent 12: 175-181.

Kennell JA, MacDougald OA (2005) Wnt signaling inhibits adipogenesis through beta-catenin-dependent and -independent mechanisms. J Biol Chem 280: 24004-24010.

Kilian KA, Bugarija B, Lahn BT, Mrksich M (2010) Geometric cues for directing the differentiation of mesenchymal stem cells. Proc Natl Acad Sci USA 107: 4872-4877.

Kim JB, Leucht P, Lam K, Luppen C, Ten Berge D, Nusse R, Helms JA (2007) Bone regeneration is regulated by wnt signaling. J Bone Miner Res 22: 1913-1923.

Kishida S, Yamamoto H, Hino S, Ikeda S, Kishida M, Kikuchi A (1999) DIX domains of Dvl and axin are necessary for protein interactions and their ability to regulate beta-catenin stability. Mol Cell Biol 19: 44144422.
Kokubu C, Heinzmann U, Kokubu T, Sakai N, Kubota T, Kawai M, Wahl MB, Galceran J, Grosschedl R, Ozono K, Imai K (2004) Skeletal defects in ringelschwanz mutant mice reveal that Lrp6 is required for proper somitogenesis and osteogenesis. Development 131: 5469-5480.

Krishnan V, Bryant HU, Macdougald OA (2006) Regulation of bone mass by Wnt signaling. J Clin Invest 116: $1202-1209$.

Kuhl M(2004) The WNT/calcium pathway: biochemical mediators, tools and future requirements. Front Biosci 9: 967-974.

Kuhl M, Sheldahl LC, Malbon CC, Moon RT (2000a) $\mathrm{Ca}^{2+} /$ calmodulin-dependent protein kinase II is stimulated by Wnt and Frizzled homologs and promotes ventral cell fates in Xenopus. J Biol Chem 275: 12701-12711.

Kuhl M, Sheldahl LC, Park M, Miller JR, Moon RT (2000b) The Wnt/Ca ${ }^{2+}$ pathway: a new vertebrate $\mathrm{Wnt}$ signaling pathway takes shape. Trends Genet 16: 279-283.

Lai HC, Zhuang LF, Liu X, Wieland M, Zhang ZY, Zhang ZY (2010) The influence of surface energy on early adherent events of osteoblast on titanium substrates. J Biomed Mater Res A 93: 289-296.

Lee YN, Gao Y, Wang HY (2008) Differential mediation of the Wnt canonical pathway by mammalian Dishevelleds-1, -2, and -3. Cell Signal 20: 443-452.

Li D, Zhou J, Chowdhury F, Cheng J, Wang N, Wang F (2011) Role of mechanical factors in fate decisions of stem cells. Regen Med 6: 229-240.

Li FQ, Singh AM, Mofunanya A, Love D, Terada N, Moon RT, Takemaru K (2007) Chibby promotes adipocyte differentiation through inhibition of beta-catenin signaling. Mol Cell Biol 27: 4347-4354.

Li X, Liu P, Liu W, Maye P, Zhang J, Zhang Y, Hurley M, Guo C, Boskey A, Sun L, Harris SE, Rowe DW, Ke $\mathrm{HZ}, \mathrm{Wu} \mathrm{D}$ (2005) Dkk2 has a role in terminal osteoblast differentiation and mineralized matrix formation. Nat Genet 37: 945-952.

Linez-Bataillon P, Monchau F, Bigerelle M, Hildebrand $\mathrm{HF}$ (2002) In vitro MC3T3 osteoblast adhesion with respect to surface roughness of Ti6Al4V substrates. Biomol Eng 19: 133-141.

Liu J, Jin T, Chang S, Czajka-Jakubowska A, Zhang Z, Nör JE, Clarkson BH (2010) The effect of novel fluorapatite surfaces on osteoblast-like cell adhesion, growth, and mineralization. Tissue Eng Part A 16: $2977-$ 2986.

Liu J, Wang X, Jin Q, Jin T, Chang S, Zhang Z, Czajka-Jakubowska A, Giannobile WV, Nör JE, Clarkson BH (2012) The stimulation of adipose-derived stem cell differentiation and mineralization by ordered rod-like fluorapatite coatings. Biomaterials 33: 5036-5046.

Lossdorfer S, Schwartz Z, Wang L, Lohmann CH, Turner JD, Wieland M, Cochran DL, Boyan BD (2004) Microrough implant surface topographies increase osteogenesis by reducing osteoclast formation and activity. J Biomed Mater Res A 70: 361-369.

Lyashenko N, Winter M, Migliorini D, Biechele T, Moon RT, Hartmann C (2011) Differential requirement for the dual functions of $\beta$-catenin in embryonic stem cell 
self-renewal and germ layer formation. Nat Cell Biol 13: 753-761.

Martin BL, Kimelman D (2009) Wnt signaling and the evolution of embryonic posterior development. Curr Biol 19: R215-219.

Masaki C, Schneider GB, Zaharias R, Seabold D, Stanford C (2005) Effects of implant surface microtopography on osteoblast gene expression. Clin Oral Implants Res 16: 650-656.

McBeath R, Pirone DM, Nelson CM, Bhadriraju K, Chen CS (2004) Cell shape, cytoskeletal tension, and RhoA regulate stem cell lineage commitment. Dev Cell 6: 483-495.

Mikels AJ, Nusse R (2006) Purified Wnt5a protein activates or inhibits beta-catenin-TCF signaling depending on receptor context. PLoS Biol 4: e115.

Miki T, Yasuda SY, Kahn M (2011) Wnt/ß-catenin signaling in embryonic stem cell self-renewal and somatic cell reprogramming. Stem Cell Rev 7: 836-846.

Milat F, Ng KW (2009) Is wnt-signalling the final common pathway leading to bone formation? Mol Cell Endocrinol 310: 52-62

Mosimann C, Hausmann G, Basler K (2009) Betacatenin hits chromatin: regulation of Wnt target gene activation. Nat Rev Mol Cell Biol 10: 276-286.

Nusse R (2008) Wnt signaling and stem cell control. Cell Res 18: 523-527.

Oh S, Brammer KS, Li YS, Teng D, Engler AJ, Chien S, Jin S (2009) Stem cell fate dictated solely by altered nanotube dimension. Proc Natl Acad Sci USA 106: 21302135.

Olivares-Navarrete R, Hyzy S, Wieland M, Boyan BD, Schwartz Z (2010a) The roles of Wnt signaling modulators Dickkopf-1 (Dkk1) and Dickkopf-2 (Dkk2) and cell maturation state in osteogenesis on microstructured titanium surfaces. Biomaterials 31: 2015-2024.

Olivares-Navarrete R, Hyzy SL, Hutton DL, Erdman CP, Wieland M, Boyan BD, Schwartz Z (2010b) Direct and indirect effects of microstructured titanium substrates on the induction of mesenchymal stem cell differentiation towards the osteoblast lineage. Biomaterials 31: 27282735 .

Olivares-Navarrete R, Hyzy SL, Hutton DL, Dunn GR, Appert C, Boyan BD, Schwartz Z (2011a) Role of non-canonical Wnt signaling in osteoblast maturation on microstructured titanium surfaces. Acta Biomater 7: 2740-2750.

Olivares-Navarrete R, Hyzy SL, Park JH, Dunn GR, Haithcock DA, Wasilewski CE, Boyan BD, Schwartz Z (2011b) Mediation of osteogenic differentiation of human mesenchymal stem cells on titanium surfaces by a Wntintegrin feedback loop. Biomaterials 32: 6399-6411.

Pan WJ, Pang SZ, Huang T, Guo HY, Wu D, Li L (2004) Characterization of function of three domains in dishevelled-1: DEP domain is responsible for membrane translocation of dishevelled-1. Cell Res 14: 324-330.

Park JW (2011) Increased bone apposition on a titanium oxide surface incorporating phosphate and strontium. Clin Oral Implants Res 22: 230-234.
Pek YS, Wan AC, Ying JY (2010) The effect of matrix stiffness on mesenchymal stem cell differentiation in a 3D thixotropic gel. Biomaterials 31:385-391.

Pereira L, Yi F, Merrill BJ (2006) Repression of Nanog gene transcription by Tcf3 limits embryonic stem cell selfrenewal. Mol Cell Biol 26: 7479-7491.

Ponik SM, Pavalko FM (2004) Formation of focal adhesions on fibronectin promotes fluid shear stress induction of COX-2 and PGE2 release in MC3T3-E1 osteoblasts. J Appl Physiol 97: 135-142.

Popelut A, Rooker SM, Leucht P, Medio M, Brunski JB, Helms JA (2010) The acceleration of implant osseointegration by liposomal Wnt3a. Biomaterials 31: 9173-9181.

Qiang YW, Barlogie B, Rudikoff S, Shaughnessy JD Jr (2008a) Dkk1-induced inhibition of Wnt signaling in osteoblast differentiation is an underlying mechanism of bone loss in multiple myeloma. Bone 42: 669-680.

Qiang YW, Chen Y, Stephens O, Brown N, Chen B, Epstein J, Barlogie B, Shaughnessy JD Jr (2008b) Myeloma-derived Dickkopf-1 disrupts Wnt-regulated osteoprotegerin and RANKL production by osteoblasts: a potential mechanism underlying osteolytic bone lesions in multiple myeloma. Blood 112: 196-207.

Qiang YW, Shaughnessy JD Jr, Yaccoby S (2008c) Wnt3a signaling within bone inhibits multiple myeloma bone disease and tumor growth. Blood 112: 374-382.

Ramires PA, Giuffrida A, Milella E (2002) Threedimensional reconstruction of confocal laser microscopy images to study the behaviour of osteoblastic cells grown on biomaterials. Biomaterials 23: 397-406.

Rodda SJ, McMahon AP (2006) Distinct roles for Hedgehog and canonical Wnt signaling in specification, differentiation and maintenance of osteoblast progenitors. Development 133: 3231-3244.

Rossol-Allison J, Stemmle LN, Swenson-Fields KI, Kelly P, Fields PE, McCall SJ, Casey PJ, Fields TA (2009) Rho GTPase activity modulates Wnt3a/beta-catenin signaling. Cell Signal 21: 1559-1568.

Rupp F, Scheideler L, Olshanska N, de Wild M, Wieland M, Geis-Gerstorfer J (2006) Enhancing surface free energy and hydrophilicity through chemical modification of microstructured titanium implant surfaces. J Biomed Mater Res A 76: 323-334.

Salasznyk RM, Klees RF, Williams WA, Boskey A, Plopper GE (2007) Focal adhesion kinase signaling pathways regulate the osteogenic differentiation of human mesenchymal stem cells. Exp Cell Res. 313: 22-37.

Sato N, Meijer L, Skaltsounis L, Greengard P, Brivanlou AH (2004) Maintenance of pluripotency in human and mouse embryonic stem cells through activation of Wnt signaling by a pharmacological GSK-3-specific inhibitor. Natural Med 10: 55-63.

Sawakami K, Robling AG, Ai M, Pitner ND, Liu D, Warden SJ, Li J, Maye P, Rowe DW, Duncan RL, Warman ML, Turner CH (2006) The Wnt co-receptor LRP5 is essential for skeletal mechanotransduction but not for the anabolic bone response to parathyroid hormone treatment. J Biol Chem 281: 23698-23711. 
Schlessinger K, Hall A, Tolwinski N (2009) Wnt signaling pathways meet Rho GTPases. Genes Dev 23: 265-277.

Schneider GB, Perinpanayagam H, Clegg M, Zaharias R, Seabold D, Keller J, Stanford C (2003) Implant surface roughness affects osteoblast gene expression. J Dent Res 82: $372-376$.

Schneider GB, Zaharias R, Seabold D, Keller J, Stanford C (2004) Differentiation of preosteoblasts is affected by implant surface microtopographies. J Biomed Mater Res A 69: 462-468.

Schwartz Z, Olivares-Navarrete R, Wieland M, Cochran DL, Boyan BD (2009) Mechanisms regulating increased production of osteoprotegerin by osteoblasts cultured on microstructured titanium surfaces. Biomaterials 30: 3390-3396.

Schwarz F, Ferrari D, Herten M, Mihatovic I, Wieland M, Sager M, Becker J (2007) Effects of surface hydrophilicity and microtopography on early stages of soft and hard tissue integration at non-submerged titanium implants: an immunohistochemical study in dogs. J Periodontol 78: 2171-2184.

Sheldahl LC, Slusarski DC, Pandur P, Miller JR, Kuhl M, Moon RT (2003) Dishevelled activates $\mathrm{Ca}^{2+}$ flux, PKC, and CamKII in vertebrate embryos. J Cell Biol 161: 769777.

Singla DK, Schneider DJ, LeWinter MM, Sobel BE (2006). wnt3a but not wnt11 supports self-renewal of embryonic stemcells. Biochem Biophys Res Commun 345: 789-795.

Smith PG, Deng L, Fredberg JJ, Maksym GN (2003) Mechanical strain increases cell stiffness through cytoskeletal filament reorganization. Am J Physiol Lung Cell Mol Physiol 285: L456-463.

Sokol SY (2011) Maintaining embryonic stem cell pluripotency with Wnt signaling. Development. 138: 43414350.

Sonderegger S, Pollheimer J, Knofler M (2010).Wnt signaling in implantation, decidualisation and placental differentiation: review. Placenta 31: 839-847.

Stamenovic D, Coughlin MF (1999) The role of prestress and architecture of the cytoskeleton and deformability of cytoskeletal filaments in mechanics of adherent cells: a quantitative analysis. J Theor Biol 201: 63-74.

Stamenovic D, Mijailovich SM, Tolic-Norrelykke IM, Chen J, Wang N (2002) Cell prestress. II. Contribution of microtubules. Am J Physiol Cell Physiol 282: C617-624.

Takao Y, Yokota T, Koide H. (2007). Beta-catenin upregulates Nanog expression through interaction with Oct-3/4 in embryonic stem cells. Biochem Biophys Res Commun 353: 699-705.

Takemaru K, Yamaguchi S, Lee YS, Zhang Y, Carthew RW, Moon RT (2003) Chibby, a nuclear beta-cateninassociated antagonist of the Wnt/Wingless pathway. Nature 422: 905-909.

Tanneberger K, Pfister AS, Kriz V, Bryja V, Schambony A, Behrens J (2011) Structural and functional characterization of the Wnt inhibitor APC membrane recruitment 1 (Amer1). J Biol Chem 286: 19204-19214.
Tu X, Joeng KS, Nakayama KI, Nakayama K, Rajagopal J, Carroll TJ, McMahon AP, Long F (2007) Noncanonical Wnt signaling through $G$ protein-linked PKCdelta activation promotes bone formation. Dev Cell 12:113-127.

Turm H, Grisaru-Granvosky S, Maoz M, Offermanns S, Bar-Shavit R (2010) DVL as a scaffold protein capturing classical GPCRs. Commun Integr Biol 3: 495-498.

Tutter AV, Fryer CJ, Jones KA (2001) Chromatinspecific regulation of LEF-1-beta-catenin transcription activation and inhibition in vitro. Genes Dev 15: 33423354.

Van Amerongen R, Mikels A, Nusse R (2008) Alternative wnt signaling is initiated by distinct receptors. Sci Signal 1: re9.

Van Amerongen R, Nusse R (2009) Towards an integrated view of Wnt signaling in development. Development 136: 3205-3214.

Van der Horst G, van der Werf SM, Farih-Sips H, van Bezooijen RL, Lowik CW, Karperien M (2005) Downregulation of Wnt signaling by increased expression of Dickkopf-1 and -2 is a prerequisite for late-stage osteoblast differentiation of KS483 cells. J Bone Miner Res 20: 1867-1877.

Van Steenberghe D, Branemark PI, Quirynen M, De Mars G, Naert I (1991) The rehabilitation of oral defects by osseointegrated implants. J Clin Periodontol 18: 488-493.

Van Tienen FH, Laeremans H, van der Kallen CJ, Smeets HJ (2009) Wnt5b stimulates adipogenesis by activating PPARgamma, and inhibiting the beta-catenin dependent Wnt signaling pathway together with Wnt5a. Biochem Biophys Res Commun 387: 207-211.

Verheyen EM, Gottardi CJ (2010) Regulation of Wnt/ beta-catenin signaling by protein kinases. Dev Dyn 239: 34-44.

Vlacic-Zischke J, Hamlet SM, Friis T, Tonetti MS, Ivanovski S (2011) The influence of surface microroughness and hydrophilicity of titanium on the up-regulation of TGFbeta/BMP signalling in osteoblasts. Biomaterials 32: 665-671.

Wall I, Donos N, Carlqvist K, Jones F, Brett P (2009) Modified titanium surfaces promote accelerated osteogenic differentiation of mesenchymal stromal cells in vitro. Bone 45: 17-26.

Wang B, Du T, Wang Y, Yang C, Zhang S, Cao X (2011) Focal adhesion kinase signaling pathway is involved in mechanotransduction in MG-63 cells. Biochem Biophys Res Commun 410: 671-676.

Wang J, de Groot K, van Blitterswijk C, de Boer J (2009a) Electrolytic deposition of lithium into calcium phosphate coatings. Dent Mater 25: 353-359.

Wang N, Butler JP, Ingber DE (1993) Mechanotransduction across the cell surface and through the cytoskeleton. Science 260: 1124-1127.

Wang N, Ingber DE (1994) Control of cytoskeletal mechanics by extracellular matrix, cell shape, and mechanical tension. Biophys J 66: 2181-2189.

Wang N, Tolic-Norrelykke IM, Chen J, Mijailovich SM, Butler JP, Fredberg JJ, Stamenovic D (2002) Cell prestress. I. Stiffness and prestress are closely associated 
in adherent contractile cells. Am J Physiol Cell Physiol 282: C606-C616.

Wang N, Tytell JD, Ingber DE (2009b) Mechanotransduction at a distance: mechanically coupling the extracellular matrix with the nucleus. Nat Rev Mol Cell Biol 10: 75-82.

Wennerberg A, Albrektsson T (2010) On implant surfaces: a review of current knowledge and opinions. Int J Oral Maxillofac Implants 25: 63-74.

Wharton KA Jr (2003) Runnin' with the Dvl: proteins that associate with Dsh/Dvl and their significance to Wnt signal transduction. Dev Biol 253: 1-17.

Williams BO, Insogna KL (2009) Where Wnts went: the exploding field of Lrp5 and Lrp6 signaling in bone. J Bone Miner Res. 24:171-178.

Wozniak MA, Chen CS (2009) Mechanotransduction in development: a growing role for contractility. Nat Rev Mol Cell Biol 10: 34-43.

$\mathrm{Xu}$ W, Kimelman D (2007) Mechanistic insights from structural studies of beta-catenin and its binding partners. J Cell Sci 120: 3337-3344.

Young SR, Gerard-O'Riley R, Kim JB, Pavalko FM (2009) Focal adhesion kinase is important for fluid shear stress-induced mechanotransduction in osteoblasts. J Bone Miner Res. 24: 411-424.

Young SR, Hum JM, Rodenberg E, Turner $\mathrm{CH}$, Pavalko FM (2011) Non-overlapping functions for Pyk2 and FAK in osteoblasts during fluid shear stress-induced mechanotransduction. PLoS One 6: e16026.

Yang F, Yang D, Tu J, Zheng Q, Cai L, Wang L (2011) Strontium enhances osteogenic differentiation of mesenchymal stem cells and in vivo bone formation by activating Wnt/catenin signaling. Stem Cells 29: 981-991.

Zhang C, Cho K, Huang Y, Lyons JP, Zhou X, Sinha K, McCrea PD, de Crombrugghe B (2008) Inhibition of Wnt signaling by the osteoblast-specific transcription factor Osterix. Proc Natl Acad Sci USA 105: 6936-6941.

\section{Discussion with Reviewer}

Reviewer I: Our next challenge for improved osseointegration is for those groups of patients where osseointegration has a poorer clinical outcome. Could the authors speculate whether developments of therapeutics for stimulating WNT signalling would have benefits for any of these compromised patients?

Authors: The real benefit with the stimulation of Wnt or other biological pathways is in those situations where success rate with standard surgical techniques would be quite low, such as in grafted areas or in compromised patients, or wherever bone regeneration is to be promoted to compensate for previous bone loss. We feel that Wnt stimulation would be an appropriate approach to promote per-implant alveolar regeneration because, although scientific evidence is still lacking, Wnt regulation is one of the likely candidate mechanisms regulating alveolar bone maintenance. There is solid evidence pointing at the pivotal anabolic role of mechanical stimulation on bone through the suppression of sclerostin and thus stimulation of Wnt signalling. It is well possible that tooth loss heavily affects alveolar bone levels through a local increase of sclerostin due to a lack of mechanical stimulation. Wnt suppression could therefore be one of the causes of alveolar bone resorption with edentulism. If this is the case, restoring an appropriate Wnt stimulation would be a physiological way to increase and maintain a healthy level of Wnt activity, and thus bone, around implants.

Reviewer I: In their review the authors focus on implant topography as a regulator of the Wnt pathway. As a guidance cue, implant topography can/should be considered along with other guidance cues that would likely exist in combination with the topography, such as surface chemical composition and implant stiffness. What are the authors views on any potential hierarchy of such guidance cues, in terms of regulating the Wnt pathway in osteogenic cells?

Authors: The reviewer's question touches upon a very important conundrum, which is hitherto still unresolved. As far as it is known, all these factors can affect the regulation of Wnt. We have shown that topography can upregulate Wnt canonical signalling, a paper from our group, which is currently in press, shows that the activation of Wnt signalling is higher in cells hyperhydrophilic modSLA surfaces, and it can be speculated that, on a tissue level, implant stiffness can affect the transmission of mechanical stimuli to the surrounding bone and indirectly modulate Wnt signalling by altering, for instance, sclerostin expression. However, little evidence is available to reach a solid conclusion about a possible hierarchy of factors. So far we have conclusive data only about signalling regulation by roughness. When it comes to hydrophilicity, we know that it does enhance Wnt canonical signalling, but we do not believe that polished hyperhydrophilic surfaces have ever been tested in this regard so we do not know the net effect of this feature on this pathway. We only know that modSLA surfaces induce a higher activation of Wnt signalling than SLA samples and polished surfaces. Again, when it comes to implant stiffness, it is likely that it can exert some sort of effect on the surrounding tissue but probably not at the cell level, at least in the stiffness range of cpTi or titanium alloys. Softer surfaces, like hydrogels, can affect cell differentiation, but we doubt that cells can discriminate between such high stiffness levels. In conclusion, probably roughness remains the key element, at least until more is known about hydrophilicity. 